Polarographic Analysis OF HMX In LX-09

B. D. Faubion

DEVELOPMENT DIVISION

APRIL - JUNE 1975

Normal Process Development Endeavor No. 223

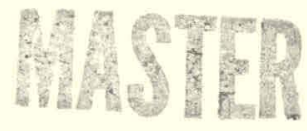

सम्सात्राi

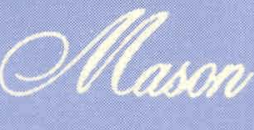




\section{DISCLAIMER}

This report was prepared as an account of work sponsored by an agency of the United States Government. Neither the United States Government nor any agency Thereof, nor any of their employees, makes any warranty, express or implied, or assumes any legal liability or responsibility for the accuracy, completeness, or usefulness of any information, apparatus, product, or process disclosed, or represents that its use would not infringe privately owned rights. Reference herein to any specific commercial product, process, or service by trade name, trademark, manufacturer, or otherwise does not necessarily constitute or imply its endorsement, recommendation, or favoring by the United States Government or any agency thereof. The views and opinions of authors expressed herein do not necessarily state or reflect those of the United States Government or any agency thereof. 


\section{DISCLAIMER}

Portions of this document may be illegible in electronic image products. Images are produced from the best available original document. 


\section{NOTICE}

This report was prepared as an account of work sponsored by the United States Government. Neither the United States nor the United States Energy Research and Development Administration, nor their employees, nor any of their contractors, subcontractors, or their employees, makes any warranty, express or implied, or assumes any legal liability or responsibility for the accuracy, completeness or usefulness of any information, apparatus, product or process disclosed, or represents that its use would not infringe privately-owned rights. 


\title{
Polarographic Analysis Of HMX In LX-09
}

\author{
B. D. Faubion \\ DEVELOPMENT DIVISION \\ April - June 1975 \\ Endeavor No. 223
}




\section{ABSTRACT}

A method for the analysis of HMX in LX-09 using differential pulsed polarography has been investigated. The polarograms were obtained on solutions of HMX in 20\% Acetone/ $80 \% 0.05 \mathrm{M}$ sodium sulfite-sodium borate buffer and in 20\%. DMSO/80\%.0.05 M sodium suTfite-sodium borate buffer. In the first solvent system the HMX is reduced at the dropping mercury electrode at a potential of $-0.825 \mathrm{~V}$ versus the saturated calomel electrode (SCE) and in the second solvent system at $-0.7 .45 \mathrm{~V}$ versus SCE. In both systems the peak heights are linear with respect to concentration over the range 0 to $100 \mathrm{ppm}$.

\section{INTRODUCTION}

The composition of LX-09 is nominally $93 \%$ HMX, 5\% poly-dinitropropyl acrylate (poly-DNPA) and $2 \%$ bis-[2-fluoro-2,2-dinitroethyl] formal (FEF0). The compositional analysis of LX-09 is normally carried out by successive extractions(1).

There is, however, a requirement for more sensitive methods of analysis in order to detect small changes in the materials which might occur during long term storage. This report discusses a method for the analysis of HMX in LX-09 using differential pulsed polarography. The application of this method for the analysis of RDX and HMX has been reported previously $(2,3)$.

\section{EXPERIMENTAL}

A Princeton Applied Research Model 174 polarographic analyzer operating in the differential pulsed mode was used to obtain the polarograms. A dropping mercury working electrode (DME), a saturated calomel reference electrode (SCE) and a platinum wire counter electrode were used for this experiment. Two mixed solvent systems were used, consisting of either acetone or dimethylsulfoxide (DMSO) mixed with a $0.05 \mathrm{M}$ sodium sulfitesodium borate buffer. With these systems it is not necessary to outgas the sample since the dissolved oxygen is removed chemically by the sulfite. The samples were prepared by dissolving HMX in 20 me of either acetone or DMSO and diluting to $100 \mathrm{me}$ with the buffer solution.

\section{RESULTS AND DISCUSSION}

Calibration samples of $10,20,50$, and $100 \mathrm{ppm} \mathrm{HMX}$ in each of the solvent systems were analyzed. In the $20 \%$ Acetone/ $80 \%$ sodium sulfite-sodium borate solvent system HMX is reduced at $-0.825 \mathrm{~V}$ versus the saturated calomel electrode (SCE). The calibration curve for this solvent system is shown in Fig. 1. The peak height is linear with concentration at least to $100 \mathrm{ppm}$. HMX is not extremely soluble in the aqueous acetone system and $100 \mathrm{ppm}$ is probably an upper limit for polarographic analysis. 
In the $20 \%$ DMSO/80\% $0.05 \mathrm{~m}$ sodium sulfite-sodium borate solvent system HMX is reduced at a potential of $-0.745 \mathrm{~V}$ versus the SCE. The calibration curve for this solvent system is shown in Fig. 2. The peak height is linear with respect to concentration at least up to $100 \mathrm{ppm}$. Since HMX is more soluble in the aqueous DMSO system it will probably be possible to run more concentrated solutions; however, the linearity above $100 \mathrm{ppm}$ has not been checked at the present time.

\section{FUTURE WORK}

Additional calibration samples of $H M X$ above $100 \mathrm{ppm}$ in the aqueous DMSO solvent system are to be run. Polarograms of FEFO and poly-DNPA in this solvent system will also be obtained to determine if they interfere with the analys is of HMX or if they can also be analyzed by this method.

Finally a procedure for the analyșis of HMX in. LX-09 will be developed. 


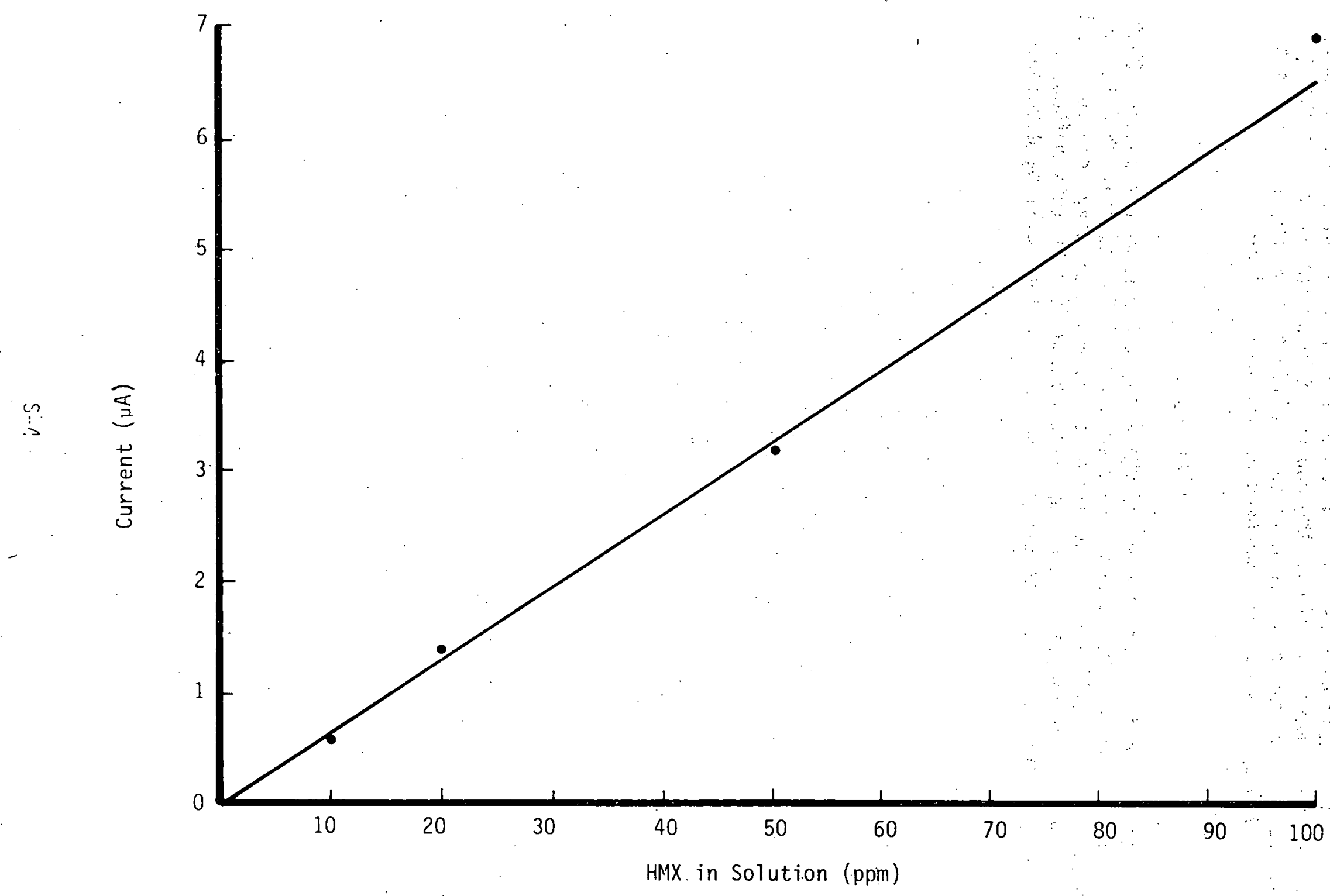

Fig. 1. HMX in 20\%/80\% Acetone/Sulfite-Borate Buffer at $-0.325 \mathrm{~V}$ versus SCE 


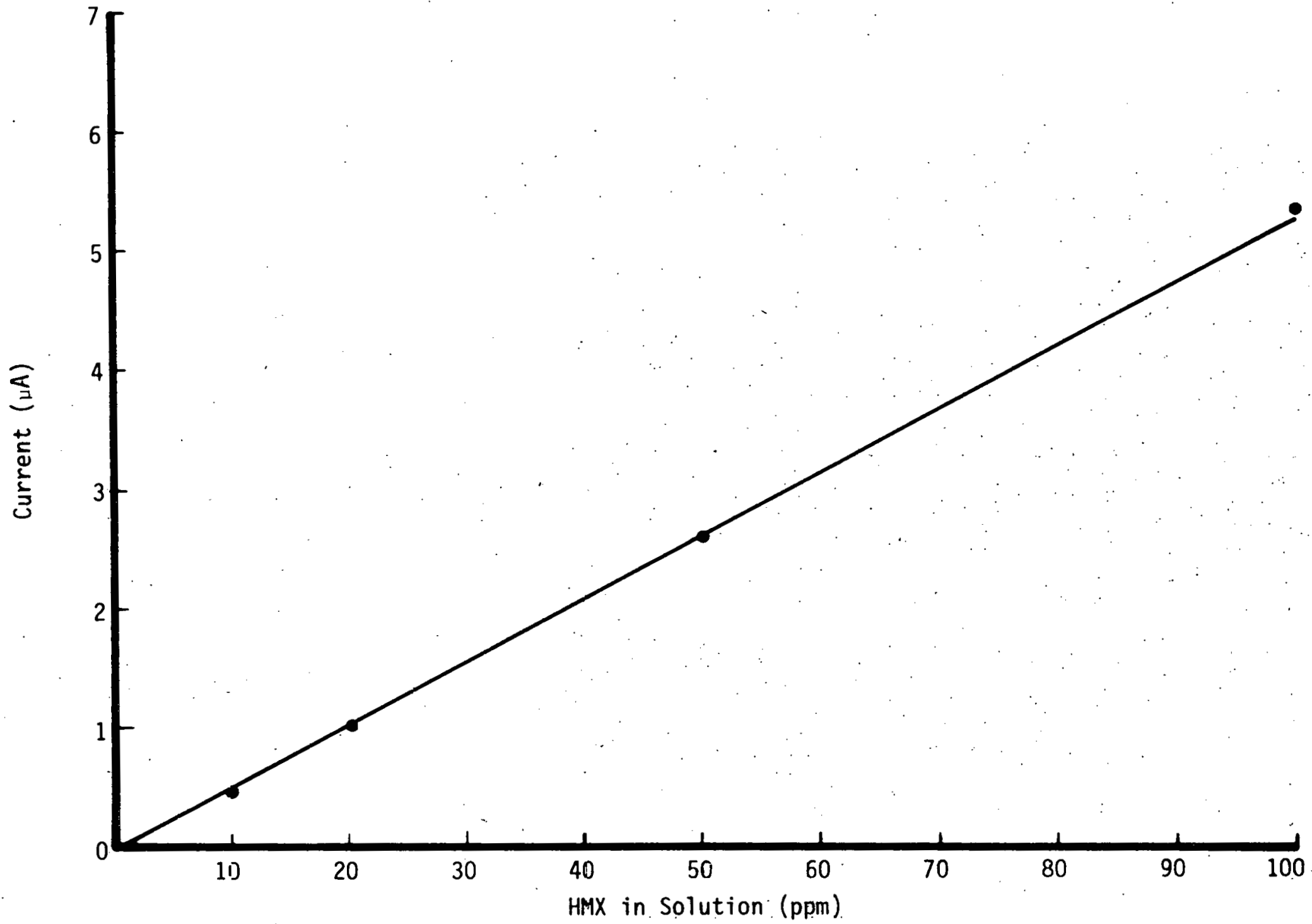

Fig. 2. Polarographic Analysis of HMX in $20 \% / 80 \%$ DMSO/Sulfite-Borate Buffer at $-0.745 \mathrm{~V}$ versus SCE 


\section{REFERENCES}

1. Walter Selig, UCRL-7873, Part II.

2. B. D. Faubion, MHSMP-73-35, April - June, 1973.

3. B. D. Faubion; MHSMP-74-9A, January - March, 1974. 